\title{
Water Resources in the area of Snyderville Basin and Park City in Summit County, Utah
}

By David D. Susong, Lynette E. Brooks, and James L. Mason

U.S. Department of the Interior-U.S. Geological Survey

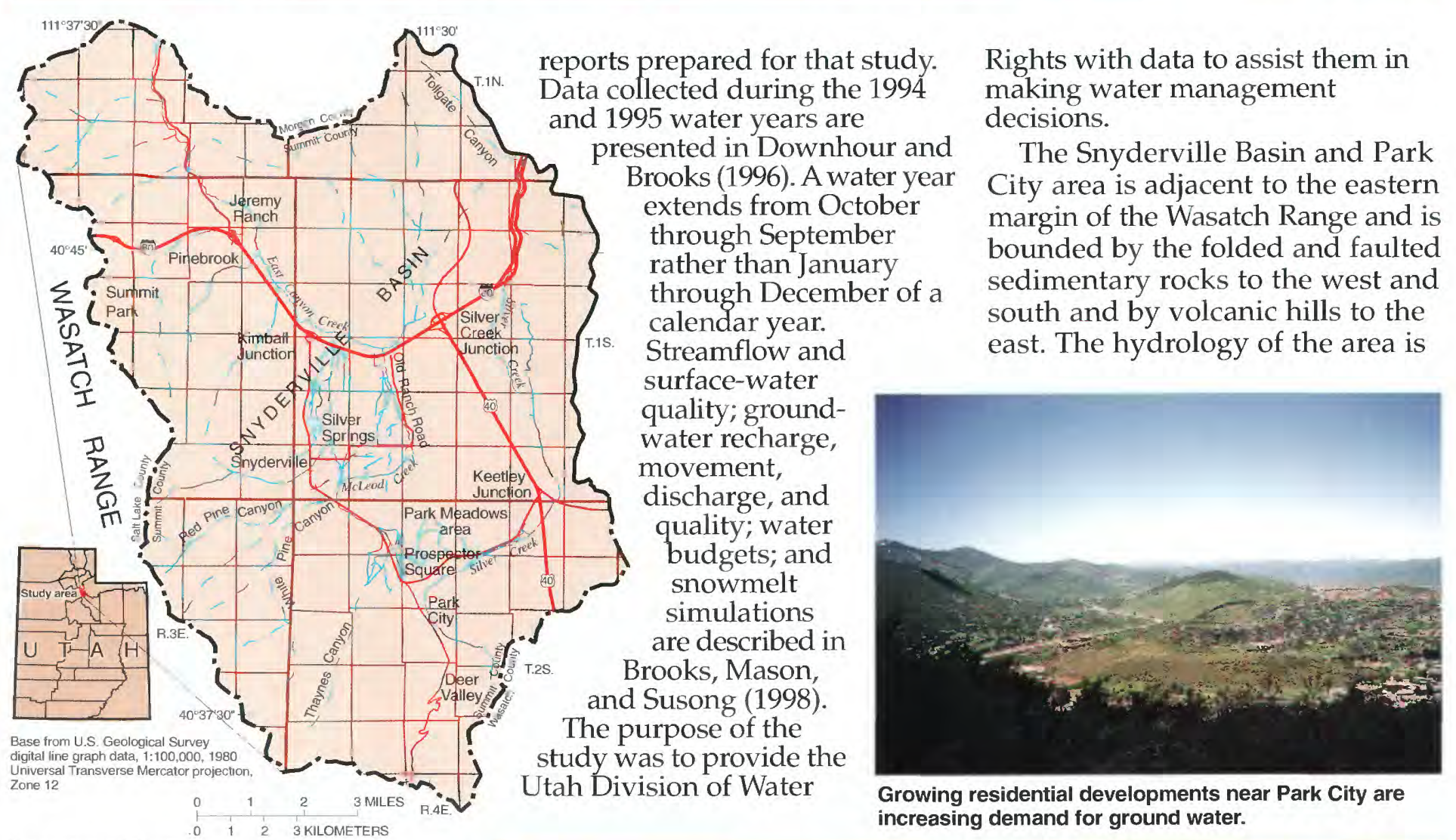

Location of study area.

\section{Introduction}

Ground water is the primary source of water for residents living in the area of Synderville Basin and Park City in Summit County, Utah. Rapid residential and commercial development are placing increased demands on the ground-water resources in the area and increased ground-water withdrawals could affect appropriated surface-water resources. The quantity and quality of water in the area were assessed during 1993-97 in a study done by the U.S. Geological Survey in cooperation with the Utah Department of Natural Resources, Division of Water Rights; Park City; Summit County; and the Weber Basin Water Conservancy District. This fact sheet presents a synopsis of the

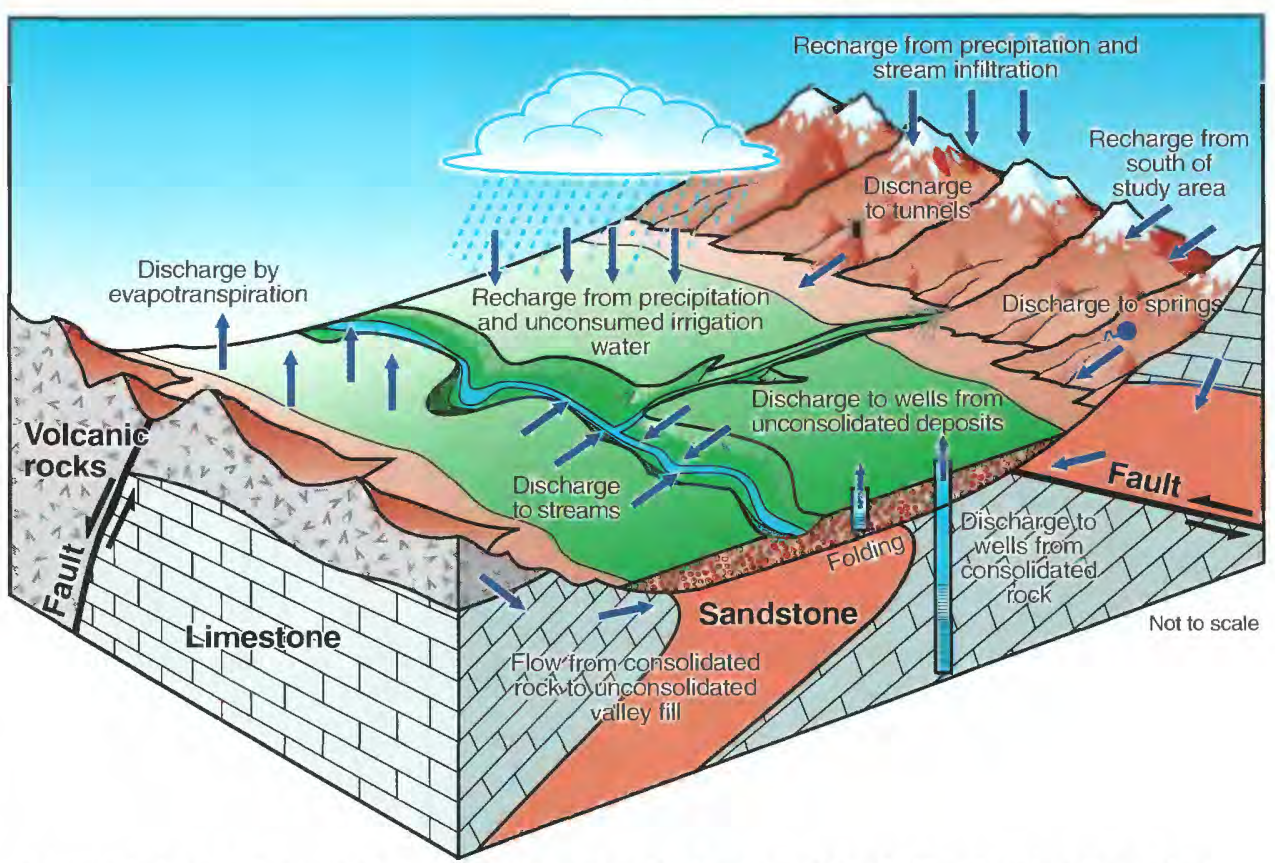

Schematic block diagram of the area of Snyderville Basin and Park City showing the waterbudget components and generalized directions of water movement. 
more complex than that of basins to the west in northern Utah. Those basins are filled with thousands of feet of unconsolidated deposits of gravel, sand, silt, and clay that serve as vast ground-water reservoirs. Snyderville Basin is filled with, at most, only a few hundred feet of unconsolidated deposits.

Ground water that is used for municipal supplies in the area is withdrawn from consolidated rocks, which consist mostly of fractured limestones and sandstones. Although sandstones contain water in the pore spaces between the sand grains, most of the recoverable water is in fractures.

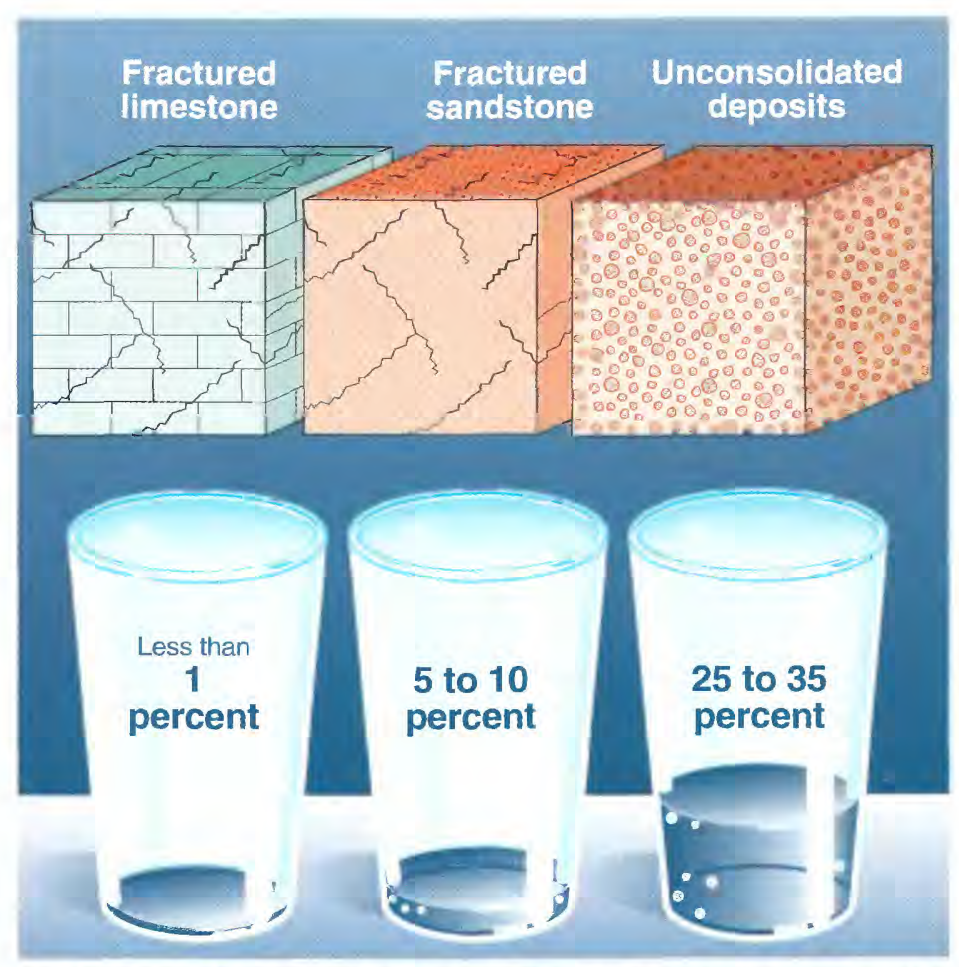

Relative percentage of void space in fractured limestone and sandstone and in unconsolidated deposits in which water can be stored. Water in consolidated rocks generally is contained within fractures; water in unconsolidated deposits is contained in pore spaces.

\section{Consolidated rocks}

have substantially less capacity to store water than unconsolidated deposits, but water can flow quickly through interconnected fractures. Consolidated rocks extend along the crest of the Wasatch Range, which is the western and southern boundary of the study area, and are continuous beneath the valley floor. Water infiltrates into the rocks at the higher elevations, flows toward the valley floor, and is discharged to wetlands, springs, and streams.

\section{Surface Water}

Surface water (water in streams, canals, lakes, and reservoirs) originates as precipitation in the Wasatch Range and leaves the study area in two streams that flow to the north, East Canyon Creek and Silver Creek. Streamflow is seasonal. During the 1994 and 1995 water years, 70 to almost 100 percent of the streamflow at gaged sites occurred during March through July.

Ground-water discharge to streams is a large component of streamflow leaving the study area, especially during late summer, fall, and winter. Ground-water discharge to streams is reduced when the water table declines. One cause of water-level decline is pumping of ground water.
Streamflow, therefore, also would decrease unless it was replenished from other sources.

\section{Ground Water}

Inflow of water to the study area is primarily from precipitation but also includes ground-water inflow from the south through consolidated rocks or through fractures that intersect mine tunnels.

Water leaves the study area by evapotranspiration, surface-water and mine-tunnel outflow, consumptive use and sublimation of snow. Generally, about 50 percent of the water is consumed within the study area. Ground water also might flow out of the study area along flow paths deep within the Wasatch Range. If ground water is leaving the study area, the ground-water budget analysis indicates that this is mostly occurring in the East Canyon Creek area.

\section{Recharge}

Ground-water recharge from precipitation made up about 80 percent of the recharge for the 1995 water year and varies yearly. Most recharge from precipitation in the study area is from infiltration of snowmelt. Precipitation as rainfall in the summer and fall months is negligible; most of it is consumed by plants. Because of the high percentage of recharge from snowmelt, groundwater levels and discharge to streams, springs, and mine tunnels are highly dependent upon winter precipitation.

\section{Discharge}

The largest component of discharge from the ground-water system is discharge to streams. During the 1995 water year, ground-water discharge to streams contributed about 40 percent of the surface water and

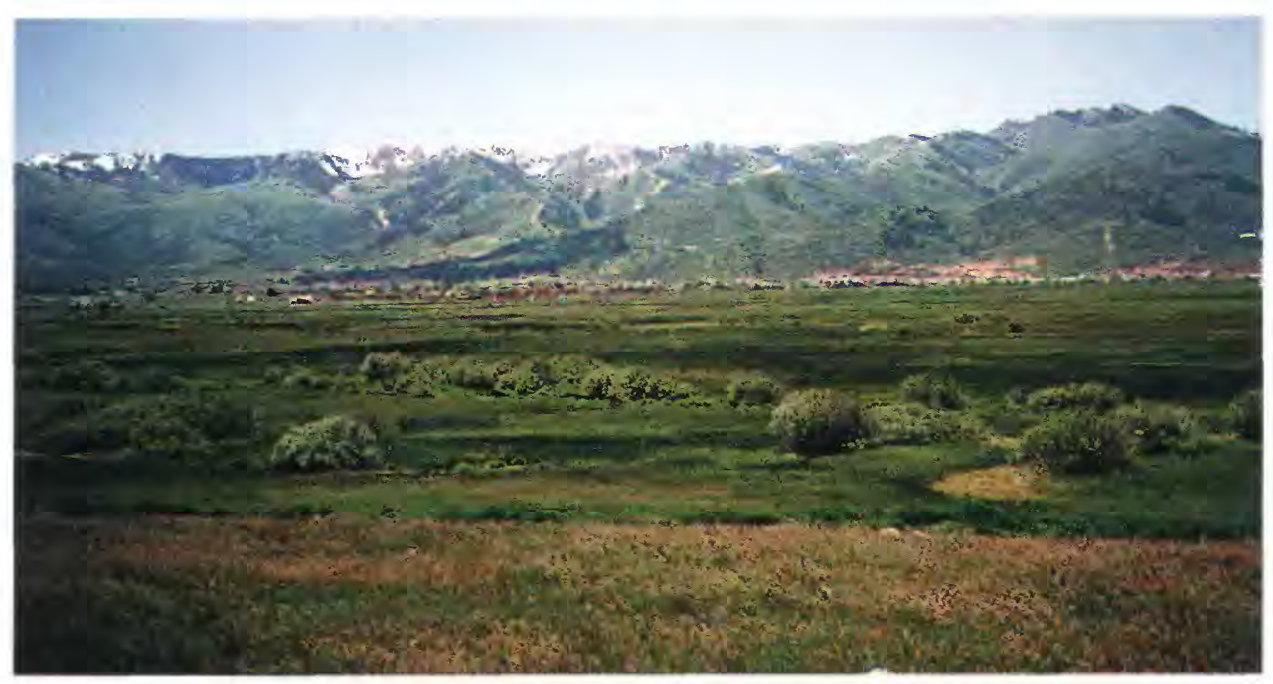

Wetlands along McLeod Creek in the Snyderville Basin area are sustained by ground-water discharge. 
ground-water discharge to springs and mine tunnels contributed about 25 percent of the surface water.

Additional development of ground water has the potential to decrease discharge to streams, springs, and mine tunnels, which could affect both the amount and quality of surface water in the study area. Much of the water used for municipal supply,

however, returns to the surface- or ground-water system as return flow from lawn watering and as treated water from wastewater-treatment plants.

The rapid increase in discharge to streams and springs as the snow melts indicates a ground-water system with only a small amount of storage capacity. This increase is a pressure response to the infiltration of water from snowmelt into the ground-water system and is not direct discharge of newly melted snow. Even though ground-water levels rise within a few weeks of snowmelt, water typically takes 15 to 40 years to move through the ground-water system.

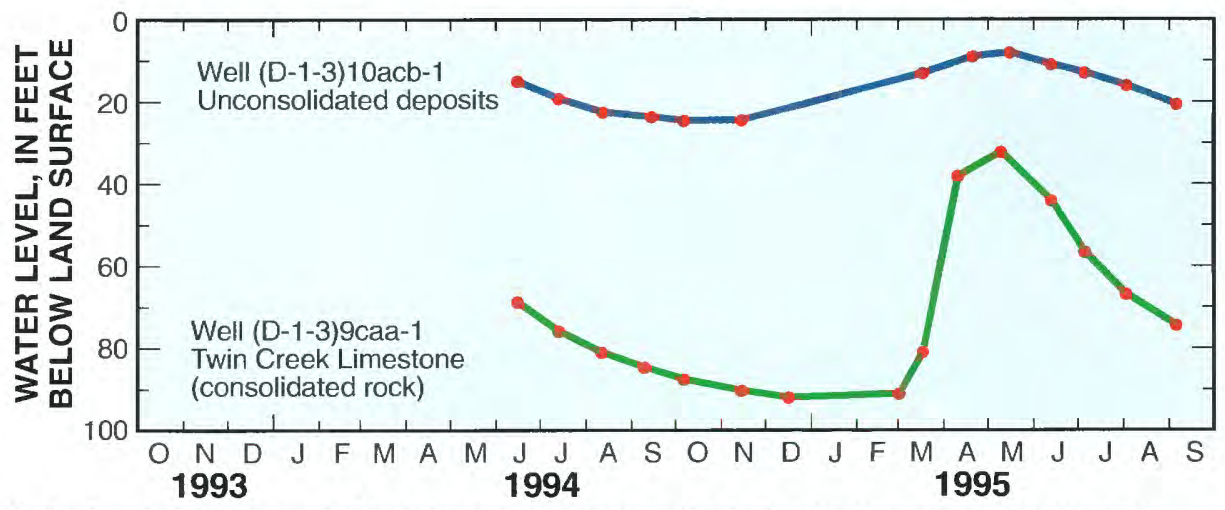

Water levels in unconsolidated deposits and consolidated rock change seasonally and depend on annual precipitation. Water levels in consolidated rock often have larger seasonal variations because there is less water stored in consolidated rock than in unconsolidated deposits.

\section{Water Budget}

During the 1995 water year, groundwater recharge exceeded discharge. The difference could be the result of errors in estimated water-budget components, increased ground-water outflow from the study area, an increase in ground-water storage, or a combination of all possibilities.

A comparison of the water budgets for the 1994 and 1995 water years
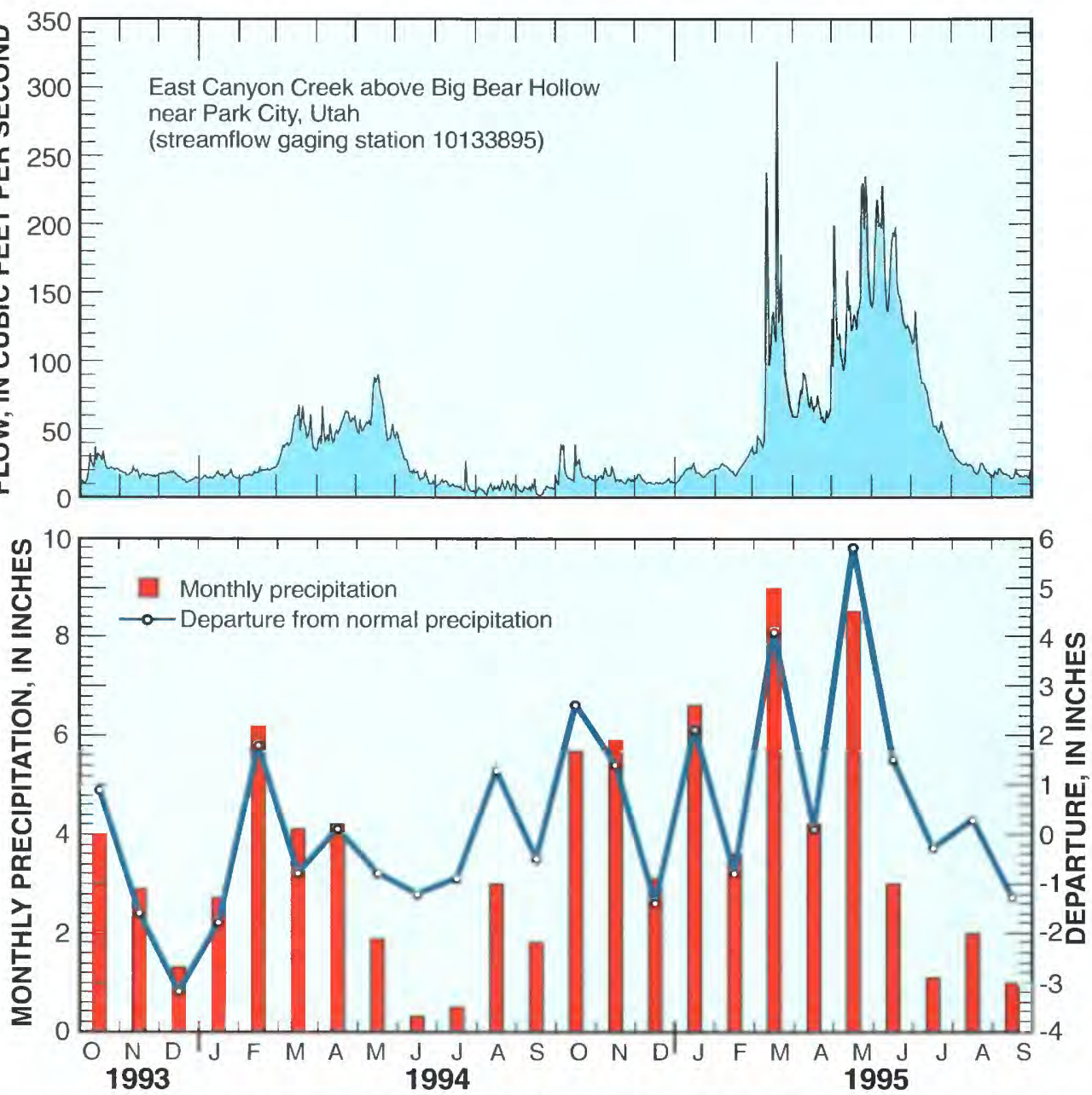

Daily average streamflow in East Canyon Creek correlates with monthly precipitation. Larger streamflows in 1995 are the result of greater-than-normal precipitation. 


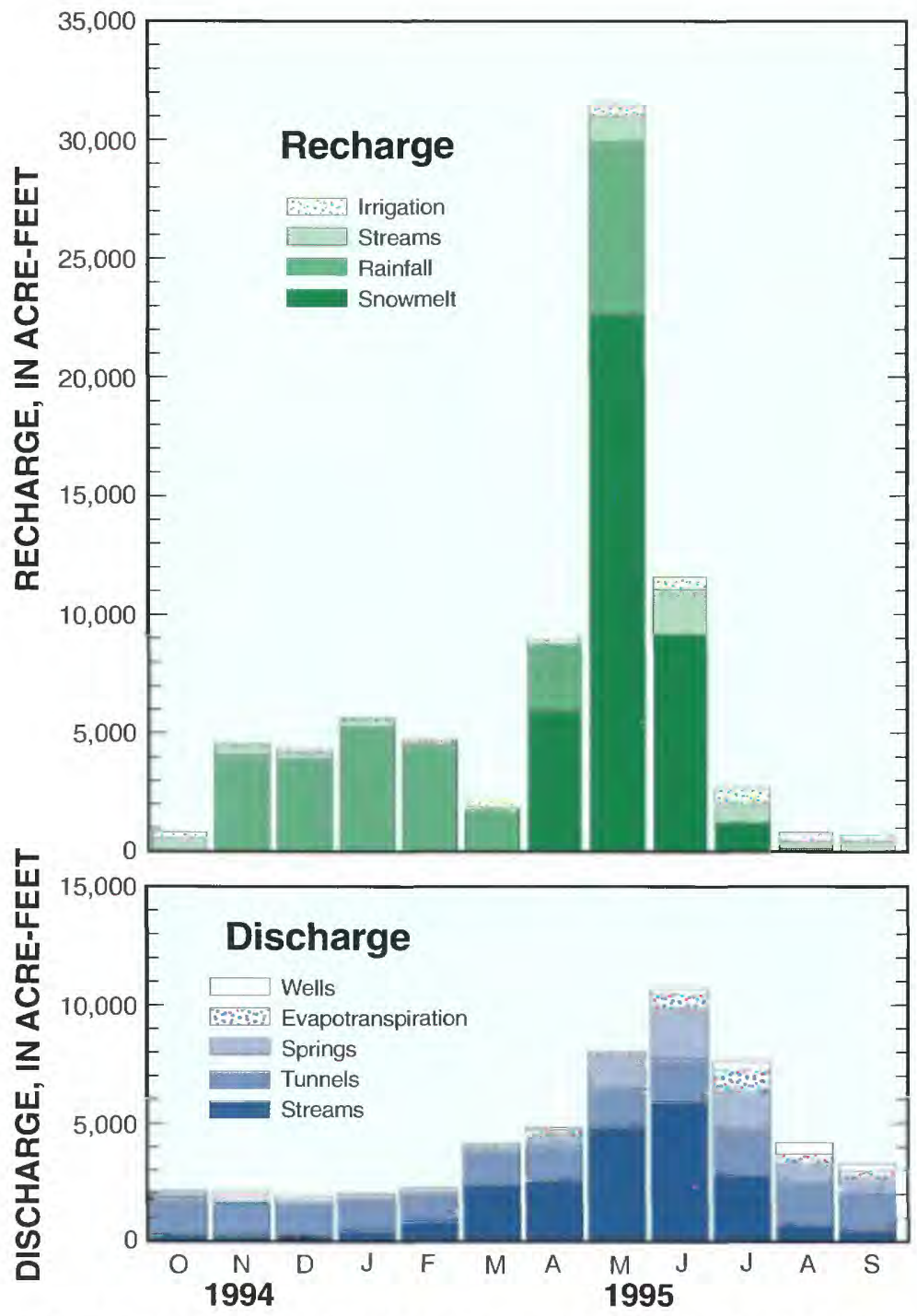

Total monthly recharge to and discharge from the ground-water system in the area of Snyderville Basin and Park City. Snowmelt is the principal source of recharge, and flow to streams is the largest component of discharge. water standards. A commonly used measure of water quality is dissolved-solids concentration, which is the total amount of dissolved chemical constituents in the water. Water from wells and springs in Snyderville Basin generally has a dissolved-solids concentration that ranges from 200 to 600 milligrams per liter, which is excellent for drinking water.

The chemical composition of ground water in the study area is influenced by the consolidated rocks through which it flows. Dissolution and weathering of limestone and sandstone contribute calcium, magnesium, and bicarbonate to the water, which affect the hardness of the water. Dissolution of gypsum in shale or gypsiferous limestone contributes calcium and sulfate to the water. Road salt contributes sodium and chloride to ground water in the unconsolidated deposits, and in some areas this water may flow into underlying consolidated rocks.

Although water samples collected from wells, springs, and drains near Park City generally have higher dissolved-solids concentrations than do ground-water samples collected elsewhere in the study area, the quality of water used for municipal supply is good. Sulfate in water discharging from mine tunnels and chloride from road salt are the probable causes of the increased dissolved-solids concentrations.

\section{Sources of Additional Information:}

Ashland, F.X., Bishop, C.E., Lowe, M., and Mayes, B.H., 1996, The geology of the Snyderville Basin and its relation to ground-water conditions: Utah Geological Survey OpenFile Report 337, 124 p.

Brooks, L.E., Mason, J.L., and Susong, D.D., 1998, Hydrology and snowmelt simulation of Snyderville Basin, Park City, and adjacent areas, Summit County, Utah: Utah Department of Natural Resources Technical Publication No. 115,84 p.

Downhour, P.A., and Brooks, L.E., 1996, Selected hydrologic data for Snyderville Basin, Park City, and adjacent areas, Summit County, Utah, 1967-95: U.S. Geological Survey Open-File Report 96-494, 52 p.

Holmes, W.F., Thompson, K.R., and Enright, M., 1986, Water resources of the Park City area, Utah, with emphasis on ground water: Utah Department of Natural Resources Technical Publication No. 85, 81 p.

Contact for hydrologic information: U.S. Geological Survey, Water Resources Division Utah District 1745 West 1700 South Salt Lake City, Utah 84104 (801) 975-3350

Contact for water-rights information: Utah Department of Natural Resources, Division of Water Rights 1594 West North Temple Salt Lake City, Utah 84114 (801) $538-7240$
Melting snow recharges the ground-water system and makes up most of the streamflow during March through July. 